\title{
COOPERATION CULTURE AMONGST KNOWLEDGE WORKERS: A CASE STUDY OF THE IT SECTOR IN POLAND
}

\author{
Anna Pietruszka-Ortyl ${ }^{*}$ \\ Cracow University of Economics, College of Management and Quality Sciences, \\ Department Of Organizational Behavior, Poland
}

The knowledge workers who form the core of the crew of a modern organization have emerged. They have a unique position in an enterprise, which complicates the incentive system building process and managers' formal impact on their activities. With a "deep-smarts" status, they adopt the attitudes that restrain or even intentionally hide knowledge flow. Providing support to organizational culture is crucial for motivating knowledge workers to contribute to an organization with their knowledge. This research paper is mainly aimed at identifying knowledge workers' preferences for organizational culture. The paper focuses on indicating the directions of the development of Polish IT companies' organizational culture in line with the attitudes of the professionals aiming to stimulate their involvement in the implementation of specific knowledge diffusion subprocesses. The paper is based upon the empirical research conducted on a sample of 105 IT sector knowledge workers in Poland in 2020.

Keywords: organizational culture, knowledge worker, knowledge diffusion, cooperation, IT sector

JEL Classification: D23, D64, D83, D91

\section{INTRODUCTION}

As a result of global changes in economic and social life and in how business is done, a modern employees' permanent learning and knowledge sharing model was formed (Costomitis, 2018). Knowledge society emerged and professionalized

* Correspondence to: A. Pietruszka-Ortyl, Department of Organizational Behavior, College of Management and Quality Sciences, Cracow University of Economics, Rakowicka 27, 31510 Cracow, Poland; e-mail: pietrusa@uek.krakow.pl itself (Tammelin, Koivunen \& Saari, 2017) and the representatives of new professions (i.e. knowledge workers (Drucker, 1999) or cognitive workers (Berardi, 2013)) simultaneously also appeared.

These individuals are an organization's most important resource (Kucharska \& Erickson, 2020), because they have the most valuable, highly contextualized, specialist and uniquely personalized knowledge (Drucker, 1999; Olsen, 2016) which is critical intellectual capital at the firm level. Therefore, 
they have a privileged position in enterprises essentially relying on the sum of their knowledge (Olsen, 2016) and managers focus their efforts on stimulating the processes of the conversion of individual knowledge into organizational knowledge. Their goal is to assimilate personalized knowledge into as many employees and other stakeholders as possible. They also aim to retain it and prevent losses emerging at the departure of key specialists (Sumbal, Tsui, Durst, Shujahat \& Ali, 2020).

Knowledge workers are fully aware of their position in the organization and the values they generate. Therefore, they are more demanding than other employees (Olsen, 2016), which complicates the structure of an adequate incentive system (Lee \& Lim, 2015) and reduces the power of managers' formal influence. As "deep-smarts" (Sumbal et al, 2020), they often live "informal life" and are not tied to any particular organization (Imafidon, 2009). They consider knowledge as power and may not be willing to entirely share their assets (Jayasingam, Govindasamy \& Singh, 2016). Then, they may deliberately limit knowledge diffusion, or they may even deliberately conceal knowledge (Arain, Bhatti, Hameed \& Fang, 2019). This is especially true when speaking about tacit knowledge (Holste \& Fields, 2010) and concerns mainly knowledge sharing (Heo, Toomey \& Song, 2019). Therefore, detailed tasks for managers to perform include providing professionals with the optimal development conditions and triggering the attitudes of openness and voluntary cooperation with all stakeholders. It is these premises that made it pertinent to understand the behavioral outcomes of the knowledge worker (Jayasingam et al, 2016).

Essentially, organizational culture is the most powerful tool for understanding people's behavior in companies (Slijepčević \& Kristić, 2019) and links to employees' beliefs, values and attitudes. It is an intangible resource determining the effectiveness of knowledge management in a company (Sun, Wang \& Gu, 2019), including the inclination to share knowledge (Bošković \& Stojanović-Aleksić, 2018) and the organizational innovation level at the same time
(Pietersen, 2017). Organizational culture is a factor beyond the level of a company's organizational capital and, consequently, the value of the entire organization. It also determines job satisfaction and job quality. Therefore, organizational culture is recognized as a stimulus for organizational knowledge flow, an organization's competitive position and market success (Sun et al, 2019).

Stimulating knowledge workers' productivity also measured by specialists' active participation in the knowledge diffusion process is the main challenge for managers (Jabagi, Croteau, Audebrand \& Marsan, 2019), which may even be more challenging than what is portrayed in knowledge management theories (Jayasingam et al, 2016). It can assume a formula consisting of the four subprocesses - knowledge acquisition (obtaining knowledge from a variety of internal and external sources), knowledge disclosure (its targeted transfer), knowledge dissemination (converting specific knowledge into a public resource) and knowledge sharing - a two-way knowledge transfer in the communication process (Mikuła, 2017).

Supporting organizational culture is vital in order to motivate knowledge workers to contribute their knowledge in an organization (Heo et al, 2019). Recognizing knowledge workers' attitudes at a very early stage will enable an organization to make better decisions and ensure end users' commitment throughout the development process (Al-Busaidi \& Olfman, 2017). In turn, high-quality employee motivation can contribute to an organization's longterm success by supporting employees' well-being and performance (Jabagi et al, 2019). Therefore, it is reasonable to concentrate efforts on shaping such an organizational culture that meets the expectations of intellectual employees related to their desired comfort zone. Providing them with an optimal environment to perform their work in triggers an attitude of openness in terms of their knowledge diffusion, which contributes to the development of organizational knowledge resources and their conversion into structural capital, thus winning a proper competitive position of the entire organization and increasing its value. 
The main research goal of the paper is to identify knowledge workers' actions and attitudes in terms of cooperation, aimed at professional knowledge diffusion rooted in enterprises' organizational culture specialists work in. In order to achieve the identified goal, the knowledge dispersion constituting subprocesses were analyzed. The weight of the individual components that create a cooperation's organizational culture across generations was also verified, with the generation's affiliation of the knowledge workers included in the survey adopted as a criterion. The study is also aimed at indicating which managerial activities and attitudes stimulate professional knowledge transfer and to what extent they are implemented.

In line with the set research goals, the following scientific hypotheses were adopted in the study:

H1: When implementing knowledge diffusion individual subprocesses (knowledge acquisition, disclosure, dissemination and sharing), knowledge workers follow different rules for each of them.

H2: In professional knowledge diffusion within various groups of knowledge agents (among specialists, between knowledge workers and the staff, between knowledge workers and cooperators), the hierarchy of values within individual collaboration principles is diversified.

H3: The importance of specific values and rules governing cooperation in knowledge diffusion differ for the representatives of each generation of knowledge workers.

These theoretical assumptions led to the following research questions:

- What principles (norms and values) of a cooperation's culture describe the organizational behavior of the professionals focused on knowledge diffusion?

- Does knowledge workers' organizational behavior based upon the cooperation's culture differ among the groups of the knowledge agents participating in knowledge diffusion?
- What activities supportive of professional knowledge diffusion are undertaken by the management of the organization, and which activities should be taken?

In order to verify the formulated hypotheses and find answers to the research questions, the triangulation method was used: qualitative and quantitative studies were combined in order to indicate the relationships between the obtained results by focusing on a specific group of respondents - the knowledge workers of the IT sector in Poland.

The paper is structured into five interrelated sections. The following Section Two is dedicated to a literature review and contains a synthesis of the literature extant in the research field. In Section Three, the choice of the research methodology is discussed, and the research sample is described. Section Four deals with the research results and discussion thereof. This part is followed the Section Five, in which concluding remarks and recommendations, as well as a presentation of the limitations of the research study and the identification of the directions for further scientific research, are given. Finally, theoretical and practical contributions to the inferences in terms of shaping the culture of a cooperation optimal for knowledge workers are highlighted.

\section{LITERATURE REVIEW}

The term "knowledge worker" was probably introduced by P. Drucker (1999), who had postulated that knowledge workers and their productivity were the most valuable assets of the organization of the $21^{\text {st }}$ century, because their work essentially implies converting information to knowledge (Lee \& Lim, 2015) by using the own potential to add some value to the organization. Such value is created through their ideas, analyses, judgments, syntheses, and designs (Horribe, 1999) and the production of knowledgebased goods and services (Erickson, Jarrahi, Thomson \& Sawyer, 2014). They apply theoretical and analytical knowledge acquired through formal education so as to develop new products or services in order to 
facilitate continuous learning (Scott, 2005) using knowledge as an input needed to obtain a knowledgebased intellectual output (Razzaq, Shujahat, Hussain, Nawaz, Wang, Ali \& Tehssen, 2019). Their work can be unpredictable, multidisciplinary, nonrepetitive, nonroutine and expert work, which involves design and technical expertise, idea generation and creative problem solving (Tammelin et al, 2017). K. Sveiby (1997) considered knowledge workers as those who were highly qualified and highly educated professionals. Therefore, formal education (Drucker, 1999) is assumed to be the condition needed to be met for entering this cognitive worker cohort (Berardi, 2005) and specialists are nowadays assumed to be the core employees of a modern and successful organization (Aydogmus, 2019).

The literature offers at least three different points of view, explaining what a knowledge worker is (Gaižauskiene \& Tunčikiene, 2016). The term „knowledge user" usually works as a theoretical construct describing the role played by specific intellectual employees in the organization rather than reflecting their assignment in the organizational structure. Most often, it is a conceptual approach, which sees knowledge workers as the most important, unique employees for an organization because of their specific style of working with knowledge. Therefore, knowledge workers are often characterized in a descriptive manner, pointing to their peculiarities and their specific employee attitudes (Lee \& Lim, 2015; Olsen, 2016). They have broad and unique expertise, as well as interpersonal competences. They focus on developing personalized, unique knowledge resources and are oriented towards building relationships and extensive professional contacts in order to exchange knowledge. They, however, work in hermetic trust circles, in two parallel worlds the virtual and the real. In their case, interpersonal relationships and personal contacts are the most important (Holste \& Fields, 2010). They look for specific groups of similar individuals, establishing practitioner (Butler, 2016) and expert (Razzaq et al, 2019) communities. Moreover, they are independent workers with an innovative attitude. They are selfreliant and mobile in their professional activities.
As a heterogeneous group, specialists can be classified into different categories of intellectual workers (Lee \& Lim, 2015). The fact that they form peculiar cohorts is also emphasized (Aydogmus, 2019) because the effective and efficient management of knowledge workers (which should be unique) belongs to the most difficult problems faced by an enterprise (Drucker, 1999; Imafidon, 2009; Jabagi et al, 2019). As a consequence, a relationship between the organization and knowledge workers should be formed (Jayasingam et al, 2016) based on mutual commitment, mutual care, interdependence, reciprocity and fairness (Tsai, 2018). It is only then that they tend to share their unique knowledge and incorporate this form of individual knowledge into organizational knowledge (Jayasingam et al, 2016).

The unique role organizational culture plays in the knowledge-based economy stems from the special importance of social communication as a platform for creating a network of interpersonal and interorganizational collaboration for the implementation of ad hoc projects.

Organizational culture is predominantly considered to be an attribute strongly associated with the specificity of a concrete organization, grounded in the values, beliefs, and assumptions held by organizational members (Dabić, Lažnjak, Smallbone \& Śvarc, 2019). It is typically understood as a shared social understanding resulting in the organization's adherents' conjoint assumptions and cliches (Savović, 2017). Therefore, it is defined as a common system of the beliefs, values, norms and customs that control and designate the organization's personnel's appropriate attitudes and behaviors (Zhang, 2018; Cillo, GarciaPerez, Del Giudice \& Vicentini, 2019). Consequently, it refers both to deeper and more enduring values and norms and to its recognizable manifestations, such as rules used in business, the code of conduct, jargon, myths, ceremonies and rituals, as well as the popular, used and characteristic ways of implementing vital management activities. For these reasons, E. Schein (1985) treats organizational culture as a set of leading values and norms of conduct specific for a certain organization, based on the assumptions that enable to understand the nature of reality. It manifests in the 
external, artificial creations, or artefacts, of a concrete culture. Hence, it seems reasonable to take actions designed to diagnose the organizational culture aimed at inferring both its overt layer in the form of cultural practice, including its visible behavior patterns difficult to decipher and its recognizable manifestations and its hidden layer in the form of a core (root), concerning unwritten rules, assumptions, expectations, and invisible mindsets (Rampersad, 2003).

Therefore, apart from the technological aspects that complement knowledge transfer space, it is recommended that efforts should mainly be made with a focus on shaping appropriate organizational culture and creating the right context for the implementation of this process using knowledge. It is desirable that the existing organizational culture evolve towards a culture promoting knowledge as a collaborationoriented exchange of intangible resources, especially knowledge sharing, fostering employee involvement and building trust, promoting teamwork, liberating a sense of community and ownership, enabling efficient communication, preferring openness to change and a proactive attitude.

For such cooperative relationships where transfer, including knowledge sharing, is a necessary activity, collaboration culture is both the foundation and the carrier of relational capital. It leads to the emergence of its specific subtype - the culture of sharing (Sun et al, 2019) and liberating pro-operational attitudes of especially intellectual workers (Jayasingam et al, 2016). The subject literature suggests that, in the process of building organizational culture which would be conducive to knowledge sharing (Stojanović-Aleksić, Erić Nielsen \& Bošković, 2019; Sun et al, 2019):

- how knowledge sharing relates to the company's goals must be indicated,

- solutions appropriate to the organization's character must be chosen (creating artifacts such as social meetings, a common language or dedicated websites),

- an appropriate incentive system must be introduced in order to encourage knowledge sharing,
- the development of contacts for knowledge sharing must be enabled,

- time for an exchange of ideas and information within communities of practice must be provided,

- knowledge sharing must be linked to the generally accepted and deeply entrenched fundamental values instead of desirable values, and

- the people who can encourage and spur others to knowledge sharing must be put at the forefront of projects and provided with all possible forms of support.

Shaping knowledge-based cooperation culture is the main task to be done by an organization's managers. Without their support and commitment, it is difficult to consciously and orderly trigger a desired employee behavior. This thesis is confirmed by the results of the conducted analysis of the subject matter literature that clearly indicates the fact that providing support to managers and encouraging knowledge sharing significantly contribute to an increase in knowledge exchange and in the intensification of all the subprocesses of its transfer (Trequattrini, Massaro, Lardo \& Cuozzo, 2019).

\section{RESEARCH METHODOLOGY AND THE SAMPLE}

Gleaning information from the aforementioned arguments, the IT sector was studied as one of knowledge-intensive sectors dominated by services, which drives the new economy (Tsai, 2018), but yet suffers from problems related to ineffective knowledge dispersion, especially concerning professional knowledge. The point of reference was the perspective of an intellectual worker as a knowledge agent. Three groups of stakeholders participating in knowledge flow were designated: the specialists, the staff and the cooperators. A total of four subprocesses constituting knowledge diffusion were also identified:

- knowledge acquisition,

- knowledge disclosure,

- knowledge dissemination and knowledge sharing. 
As a result, the main goal of the study was to identify the elements of organizational culture that constitute cooperation aimed at diffusing professional knowledge in terms of an internal and external exchange between professionals and between specialists and the staff. In particular, the focus was on the identification of the managers' supporting activities and attitudes stimulating professional knowledge transfer. Knowledge professionals as a group of peculiar cognitive cohorts were additionally assumed to significantly differ from each other in their respective attitudes, values and preferences for the cooperation culture building principles due to the generation's individual members' affiliation. In order to verify this thesis, a comparison was made between the $X$ generation and the other, younger generations $(\mathrm{Y} \text { and } \mathrm{Z})^{1}$.

A three-stage research procedure was applied, including a direct semi-structured individual interview (the interview scenario), FIGO (focus group online interviews - one focus for each knowledge diffusion dimension: between the knowledge workers, between the professionals and the staff, between the specialists and the external stakeholders), as well as CATI and CAWI.

The first stage in the form of the conceptualization phase was based on a critical analysis and the evaluation of the literature on professional knowledge transfer and the vital role of organizational culture for its effectiveness. This phase was supported by a semi-structured individual interview, with an interview scenario as the leading tool. As a result, the critical components of the organizational culture of the cooperation established between the IT professionals were identified and the preliminary research hypotheses were formulated. The second stage (the concept verification phase) is the stage at which a focus group online interview was conducted with the purpose of consulting the formula questions and scrutinizing the level of understanding the terms used in_them, simultaneously adapting the language and terminology used in the research tool to the mental models of specific employee generations of the IT specialists. Thus, the final research hypotheses were formulated, and the research questionnaire was independently constructed constituting the starting point for the third stage - the in-depth research phase, based on the computer-assisted telephone interview and the computer-assisted web interview. The questionnaire was constructed specifically to verify the hypotheses of this study and the same included the questions dedicated to indicating which of the values and norms, beliefs and assumptions, as well as attitudes and standard rituals (selected as a result of the earlier stages of the qualitative research) were significant, characteristic, typical and representative for the specific generations of the knowledge workers in the IT sector in the context of professional knowledge transfer within the framework of its subprocesses. The respondents were asked both in the context of the existing and in the context of the preferred components of organizational cooperation culture defined in the language and terminology consistent with the cognitive schemas and stereotypes they represented.

Based upon the questionnaire that consisted of the 33 questions based on a 7-point Likert scale, the survey in question was carried out in the spring of 2020. As many as 105 fully completed questionnaires were obtained out of the 397 forwarded research questionnaires. As a consequence, a total of 437 single variables were obtained. Some of them related to the analysis and diagnosis of the overt and the hidden layers of organizational cooperation culture characterizing the professionals as a group constituting the Polish IT sector knowledge workers' cohort. The others referred to the conditions, attitudes, beliefs and activities in the knowledge dispersion field in the context of the knowledge dispersion of the specialists included in the survey. In the context of exploring the hidden layer of organizational culture, i.e. in the context of exploring its core, a decision was made to verify the basic assumptions, the unwritten rules and the expectations, as well as the standards and values in force in the knowledge community. In the case of exploring the overt layer, a decision was made to check the applicable rituals and customary procedures, or the activities considered as fundamental by the specialists. Such optics remained in line with E. Schein (1985) or the H. Rampersad (2003) organizational culture component concept. 
The respondents themselves were professionals ${ }^{2}$ (17.14\% of them were women and $82.86 \%$ were men) with higher education (93.3\%), representing the generations X (74.3\%), Y (22.85\%) and Z (2.85\%), with the established professional positions $(46.67 \%$ were the specialists, $23.82 \%$ accounted for the managers, $19.05 \%$ held the position of the director, $10.46 \%$ were Board members) and an average seniority of 17 years.

To verify the hypothesis about the existence of the relationships between the variables, a significance test for Spearman's rank-order correlation coefficient was done. The null hypothesis stated in the test assumed no relationship at all between the variables $\left(\mathrm{H}_{0}: \mathrm{p}_{\mathrm{s}}=0\right)$. The fact that the null hypothesis at the significance level of $\alpha=0.05$ was rejected allowed the adoption of an alternative hypothesis stating that there was a relationship between the variables $\left(\mathrm{H}_{1}: \mathrm{p}_{\mathrm{s}} \neq 0\right.$ ) (Aczel \& Sounderpandian, 2018) ${ }^{3}$.

On the other hand, to compare the importance of the particular behavior standards for the employees belonging to different generations, the WilcoxonMann-Whitney test was done. It enabled us to verify the research hypothesis saying that the individual samples had been taken from the populations with the equal medians (at the significance level $\alpha<0.05$ ). It implied the ranking of the values of the dependent variable (from the lowest to the highest) in the study groups, which was followed by a comparison of the study groups (Aczel \& Sounderpandian, 2018). The prerequisite for doing the test was measuring the analyzed variables on at least the ordinal scale. Although no group equality was required for the Wilcoxon-Mann-Whitney test, the representatives of the generations $\mathrm{Y}$ and $\mathrm{Z}$ were combined into a single group due to the fact that only three representatives of the generation $\mathrm{Z}$ took part in the study. The fact that the null hypothesis was rejected allowed us to demonstrate the fact that there were statistically significant differences between the generations $X, Y$ and $\mathrm{Z}$ in terms of the studied variables.

The first two hypotheses were tested by means of Spearman's correlation coefficient, whereas the third hypothesis was verified by means of the nonparametric Mann-Whitney U group comparison test.

\section{RESEARCH RESULTS AND DISCUSSION}

Initially, a decision was made that the organizational cultures in which the knowledge workers included in the survey were operating would be explored and that the fact whether they were really knowledge-oriented and collaborative cultures would be verified. For that particular reason, the current and the preferred behavior standards were subjected to examination. The largest number of the studied knowledge workers indicated as binding and desirable those features that proved that the organizational cultures of their respective companies had been evolving towards knowledge-based cultures, or that they already represented one of their types, which included conduct mainly based on values, continuous training and education, shared responsibility, seeing knowledge sharing as a value, an open door policy, an accommodating attitude and the focus on the key employees (Pietruszka-Ortyl, 2020).

The obtained results confirm the specificity of the IT sector based on intangible resources and the service economy. What causes a concern is the professionals' preferences for the "knowledge $=$ power" principle, which suggests that some knowledge agents consider knowledge to be the basis of their power, which may significantly limit its diffusion. In addition, the specialists want a greater focus on the key employees, values, shared responsibility, and greater incentives to share knowledge. Thus, the obtained answers set the course of shaping the organizational cultures of the enterprises which the respondents work in.

The study results allowed a more advanced analysis of the values and principles constituting the cooperation culture amongst the knowledge workers. The relationship between the individual components of the knowledge diffusion subprocesses and the indicated norms and values of cooperation culture was sought (Table 1), and the differences in the hierarchy of the indicated principles originating due to the generation affiliation of the respondents were verified as well (Table 2) ${ }^{4}$.

In the case of knowledge acquisition, the professionals basically focus on the key employees. They strive to acquire knowledge only from experts, simultaneously 
underestimating informal communication, the use of an open-door policy and customer orientation. These attitudes are not broadly accepted, probably not so due to the applied knowledge protection strategies. Limiting oneself to loyalty towards the own domain is part of internal competitive attitudes and is rooted in the evolutionary market approach, where the strategic business unit is a quasi-enterprise, and the organization is not holistically treated as a bundle of resources.

The use of limitations in free and uncontrolled knowledge diffusion is also confirmed by the negative correlations of each subprocess of knowledge exchange with the attitudes of openness, customer orientation $(-0.2253 ;-0.2037 ;-0.2086)$ and the open-door policy $(-0.2342 ;-0.2785 ;-0.3175 ;-0.3463)$ being their emanations. Knowledge disclosure and knowledge dissemination are facilitated by a rigid division into organizational units $(0.3720 ; 0.4302)$, the focus on the key employees $(0.3523 ; 0.3194)$, unrestricted access to management $(0.3519 ; 0.4164)$, cross-functional teams (0.3385; 0.3319$)$ and authority based on expertise $(0.3141 ; 0.2407)$. Such results confirm the fact that specialists are the main carriers of knowledge in an organization and indicate a clear polarization of activities carried out and the attitudes held by knowledge workers. Membership in specific cohorts triggers collaboration, and affiliation with specific organizational units exerts an influence on internal loyalty and strengthens trust. At the same time, it restricts cooperation, reducing the chance to generate the non-personalized, innovative organizational knowledge based upon different perspectives, which is characteristic of cross-functional teams.

As a professional knowledge diffusion component, the knowledge sharing subprocess is considered to be the most important in the subject-matter literature. When participating in it, intellectual workers primarily pay attention to unrestricted access to the management (0.4433), limiting themselves to the hermetic units (0.4051) of similar professionals (0.2682). They also confirm treating knowledge as the foundation for power $(-0.2505)$ and conservatism in unrestricted knowledge sharing, which goes beyond the community of trusted specialists. On the other hand, the indication of the principle of evenly distributed responsibility in each of the knowledge diffusion subprocesses $(0.2371 ; 0.2516 ; 0.3319 ; 0.2661)$ signals the upcoming change in and the pursuit of a culture of shared responsibility capable of inducing a culture of cooperation and, ultimately, a culture of sharing.

Table 1 Spearman's correlation rank matrix for the variables of the knowledge diffusion subprocesses and the principles of the culture of sharing

\begin{tabular}{l|cccc}
\hline Behavior standards & Acquisition & Disclosure & Dissemination & Sharing \\
\hline Rigid organizational division & 0.1321 & $0.3720^{*}$ & $0.4302^{*}$ & $0.4051^{*}$ \\
Unrestricted access to management & $0.2063^{*}$ & $0.3519^{*}$ & $0.4164^{*}$ & $0.4433^{*}$ \\
Focus on key employees & $0.4373^{*}$ & $0.3523^{*}$ & $0.3194^{*}$ & $0.2682^{*}$ \\
Sharing knowledge as a value & -0.1601 & -0.1601 & $-0.2096^{*}$ & $-0.2505^{*}$ \\
Expert power & 0.1725 & $0.3141^{*}$ & $0.2407^{*}$ & 0.0806 \\
Informal ways of communicating & $-0.2561^{*}$ & $-0.2496^{*}$ & $-0.3106^{*}$ & $-0.3098^{*}$ \\
Equally distributed responsibility & $0.2371^{*}$ & $0.2516^{*}$ & $0.3382^{*}$ & $0.2661^{*}$ \\
Cross-functional teams & 0.0652 & $0.3385^{*}$ & $0.3319^{*}$ & 0.1263 \\
Customer orientation & $-0.2253^{*}$ & -0.1678 & $-0.2037^{*}$ & $-0.2086^{*}$ \\
Open-door policy & $-0.2342^{*}$ & $-0.2785^{*}$ & $-0.3175^{*}$ & $-0.3463^{*}$ \\
\hline
\end{tabular}

${ }^{*} \mathrm{p}<0.05$

Source: Author 
In addition, the respondents' preferences for the importance of the specific behavior standards emanating a knowledge dispersion-based cooperation culture were explored. The anti-principles of the cooperation culture based on knowledge exchange were introduced as controlling. The highly negative results of the correlation coefficients for the compared groups only confirm the adoption of the cooperationoriented attitudes and activities and the emergence knowledge-based cooperation culture (Table 2). An attempt was made to compare the generation X's representatives' priorities (1965-1979: group X) against those of the generation Y's (1980-1989) and the generation Z's (1990-) representatives included in a single comparative group (the YZ group).

As dominant in the research study and highly represented on the IT knowledge-workers (especially managers) market, the generation $X$ was adopted as the reference group. This is the age when the professional status, experience and autonomy in the workplace predispose one to a position of an intellectual worker in the organization. The preferences of this generation were compared with those of the representatives of the younger generations as knowledge agents involved in knowledge dispersion.
It was observed that, for the variables "Expert power", „Equally distributed responsibility”, „Crossfunctional teams" and the "What can I do for you? attitude", the generations $\mathrm{Y}$ and $\mathrm{Z}$ had a higher mean value than the generation $X$. The situation is quite an opposite one for the variables „Outward orientation”, "Unrestricted access to managers" and the "What's in it for me? attitude". Such results justify the conclusion that the generation $X$ knowledge workers are more outward-oriented and look for knowledge sources outside their home organization, focusing on cooperation relations within a network. On the other hand, younger specialists look for knowledge resources within their own organizations, rejecting the hierarchy and preferring equally distributed responsibility and cross-functional teams, giving up expert authority at the same time. They demonstrate more egalitarian than elitist attitudes, promoting collaboration, community and sharing. These guidelines can be valuable especially for the generation $X$, who are usually in the managerial positions. Suggestive are similar results for the variables: the "What's in it for me?" attitude (a higher value for the generation $X$ ) and "What can I do for you?" (a higher value for the generations $Y$ and $\mathrm{Z}$ ). They prove that, regardless of the generation

Table 2 The Wilcoxon-Mann-Whitney test for two generation groups - the generation X (78 respondents) and the generations $\mathrm{Y}$ and $\mathrm{Z}$ (27 respondents)

\begin{tabular}{|c|c|c|c|c|c|c|c|}
\hline Behavior standards & $\begin{array}{l}\text { Sum of the } \\
\text { ranks in the } \\
\text { group X }\end{array}$ & $\begin{array}{l}\text { Sum of the } \\
\text { ranks in the } \\
\text { group YZ }\end{array}$ & U & Z & $\mathrm{p}$-value & $\begin{array}{l}Z \text { correct } \\
\text { ed }\end{array}$ & $p$-value \\
\hline Outward orientation & 1867.50 & 3697.50 & 616.50 & 3.1967 & 0.0014 & 3.5883 & 0.0003 \\
\hline $\begin{array}{l}\text { Unrestricted access to } \\
\text { management }\end{array}$ & 1887.00 & 3678.00 & 597.00 & 3.3396 & 0.0008 & 3.7860 & 0.0002 \\
\hline $\begin{array}{l}\text { „What's in it for me?" } \\
\text { attitude }\end{array}$ & 1754.00 & 3811.00 & 730.00 & 2.3645 & 0.0181 & 2.5520 & 0.0107 \\
\hline Expert power & 1062.00 & 4503.00 & 684.00 & -2.7018 & 0.0069 & -2.9759 & 0.0029 \\
\hline $\begin{array}{l}\text { Equally distributed } \\
\text { responsibility }\end{array}$ & 1104.00 & 4461.00 & 726.00 & -2.3938 & 0.0167 & -2.6674 & 0.0076 \\
\hline $\begin{array}{l}\text { Cross-functional } \\
\text { assemblies }\end{array}$ & 884.00 & 4681.00 & 506.00 & -4.0068 & 0.0001 & -4.4049 & 0.0000 \\
\hline $\begin{array}{l}\text { „What can I do for you?" } \\
\text { attitude }\end{array}$ & 1152.00 & 4413.00 & 774.00 & -2.0419 & 0.0412 & -2.3453 & 0.0190 \\
\hline
\end{tabular}

Source: Author 
represented by the specialists, they are open to the cooperation based on an effective motivation system. Therefore, it is necessary to create a comprehensive model for managing professionals which will focus on their knowledge diffusion.

The unrestricted access to management rule significantly defined the course of all the analyzed knowledge diffusion subprocesses and was indicated as critical, regardless of the generational affiliation of the knowledge workers included in the survey. Therefore, efforts were made to identify the management areas in terms of stimulating knowledge diffusion, as well as the management's attitudes and actions aimed at exchanging knowledge, thus examining the scope of managerial support in the knowledge exchange processes. The respondents indicated the fact that the managers inspired and motivated them to exchange knowledge („He/she supports and encourages knowledge sharing" - 74.3\%, "He/she encourages and inspires me to take action" - $80 \%$, "He/she motivates me to cooperate" - 83.8\%) by creating favorable conditions $(, \mathrm{He} /$ she facilitates knowledge sharing" - 76.2\%, „He/she supports employee development initiatives” - 76.2\%, „He/she encourages collaboration" - 81.9\%). To the smallest extent, they actively participate in the knowledge circulation processes (70.5\% of the responses), which may hinder its flow in the hierarchical dimension. Superiors are not role models then although they should also play this role in knowledge-based organizations and encourage everyone to be open in knowledge dispersion by their own example.

Based on the comparative analysis of the actions taken and the activities suggested by the respondents, potential areas for improving management skills were also designated. The guidelines from the responses can be presented as directives: focusing on building trust $(92.4 \%)$, introducing an appropriate motivational system encouraging knowledge dispersion (90.5\%), selecting appropriate project leaders - the people who can cheer others up and enthuse others with the idea of knowledge sharing and provide all required support $(88.6 \%)$ and enabling the development of the communities of practice $(85.7 \%)$. The orientation towards shaping communication openness (41.9\%) and networking is not the main priority (42.85\%).
Such a point of view is probably related to the character of professional work. These activities are its indispensable element and specialists undertake and implement them regardless of the organizational context.

\section{CONCLUSION}

Time and an effort, especially time and an effort on the part of the management of organizations, are required for organizational culture to change. Managers must be convinced that it is worth shaping its development in such a way as to reach cooperation culture. However, achieving this level requires striving. It is much easier to change the organizational climate and, by shaping it, exert an influence on organizational culture in the long run. Therefore, it is first and foremost recommended that an atmosphere of coherence and openness supported by an appropriate social system infrastructure should be created.

The evolution towards reaching the level of knowledge-based cooperation culture imposes that we should remember that to start a culture like that, such culture should be a culture of knowledge sharing or cooperation based on the attitudes and values considered as key to cooperation culture. Participants in the knowledge transfer process must have a deep inner conviction that, according to the network perspective, knowledge dispersion implies a larger number of opportunities.

Based on the analysis, the hypotheses put forward in the study were confirmed. It was proven that, in the case of the individual knowledge diffusion subprocesses implementation and the various groups of knowledge agents participating in those subprocesses, professionals assign a different meaning to specific behavior standards. The critical importance of the support given by the managers who act as role models was also confirmed. Management should favor teamwork, help individuals improve and broaden their competences, and reward any initiative for voluntary knowledge diffusion at all levels as well. 
The presented considerations provide specific tips on which components of cooperation culture should be developed, bearing in mind participants in the professional knowledge transfer process, as well as the partial process of its diffusion. The generation preferences for the particular knowledge exchange behavior standards that may significantly improve professional knowledge intergenerational diffusion were also taken into account.

The knowledge workers included in the survey were found not to be supportive of the idea of equal opportunities for all the stakeholders of the organization. They are aware of their key role in the enterprises which they work for due to their unique competences. Therefore, they support the activities focusing on the key employees, expecting such attitudes from their superiors and demonstrating such organizational behaviors themselves. They are simultaneously cooperation-oriented, but within their own groups, organizational affiliation and the level of competence being the barrier to their entrance. On the other hand, in order for professional knowledge diffusion to be effective and result in free, targeted circulation between all groups of knowledge agents, cooperation culture should transform into a culture of cooperation encompassing all organizational units and actors within the enterprise. The main value should be knowledge sharing and restricting protectionist attitudes in knowledge exchange. This is to be achieved by a properly designed motivational system promoting openness and active participation in knowledge dispersion, based on the guidelines obtained in the course of the research. It should be a component of a comprehensive knowledge worker management system, taking into account their value systems and attitudes also in the perspective of generational differences. It is then that it can be a model solution for most organizations, taking into consideration the main values, general and specific rules relating to knowledge diffusion. Knowledge, trust, openness and support should be the main values. As part of the general principles, they should be expressed in communication and mutual interactions, knowledge sharing, searching for diversity and continuous learning. In particular, these should be visible in intensifying direct contacts, leaving room for spontaneous and informal events and behaviors, searching for and triggering constructive criticism and developing common mental models.

The paper theoretically and practically contributes to research in the social determinants of professional knowledge diffusion in terms of cooperation between knowledge workers as members of specific cohorts. It organizes theory and formulates practical guidelines in terms of shaping knowledge-diffusionbased cooperation culture optimal for cooperation between and among intellectuals. They are concisely articulated and discussed in the study conclusion formula. The paper also identifies the actions undertaken and attitudes expressed by management, which are desirable in terms of stimulating knowledge flow. Moreover, it outlines directions and provides leads for shaping the concrete elements of the organizational cooperation culture professed, desired and preferred by professionals, simultaneously highlighting the highly probable drawback areas.

There are many limitations to this research study due to its being narrow in character and its limited scope. Therefore, the results discussed herein should only be treated as an illustration because of the limited research sample. The research study neither identifies the unambiguous and evidently strong correlations between the explored variables nor does it clearly discern the directions of the studied dependences. Moreover, the analysis proved that some results could not be generalized for the entire population of IT knowledge workers in Poland, but the same can only be explored in the context of the verified respondent group. Nevertheless, they indicate which cooperation rules aimed at knowledge diffusion should be applied, which of the rules are effective, which rules should be implemented and supported as emerging, universally applicable standards. This knowledge of organizational cooperation culture amongst knowledge workers brings a crucial benefit for managers - it delivers informal means of creating organized activities (the language, social norms, the folklore, ceremonies), offers common mental models and a conceptual apparatus - being vital for professional knowledge dispersion throughout the organization, defines generational group boundaries, 
the acceptance and rejection criteria in the context of voluntary knowledge flow.

The conducted preliminary explorations pose new research challenges and set directions for further scientific research to be done. One of them will be the identification of the relationship between the principles that constitute a comprehensive professional knowledge diffusion system and individual knowledge transfer subprocesses from the perspective of intergenerational differences and the implemented organizational functions. The other challenge is the diagnosis of the differences between the existing and the preferred organizational behaviors, which would determine the course of the evolution for knowledge-exchange-oriented organizational cooperation culture.

\section{ENDNOTES}

1 The representatives of the generations $Y$ and $Z$ were treated as a single research group for the following three reasons: 1) the representatives of the generation $X$ are the largest research group with critical competences for the IT sector in Poland (Kmiotek \& Kopertyńska, 2018), 2) the generation Y is reported to scientifically differ from the earlier generational cohorts (Mahmoud, Fuxman, Mohr, Reisel \& Grigoriou, 2020), and 3) the generations $Z$ and $Y$ are found by scholars to share common characteristics (Wood, 2013).

2 The group of the respondents follows the division of the key employees into knowledge workers (e.g. IT specialists) and management professionals (e.g. managers), often cited in the literature (Olsen, 2016).

3 The interpretation of Spearman's rank-order correlation coefficient is analogous to the interpretation of the parametric Pearson correlation coefficient.

4 The study of the correlation between the specific principles and the subprocesses that constitute knowledge transfer, as well as a comparative analysis of the employee generations and their preferences against the individual norms and values of the cooperation culture aimed at knowledge diffusion confirmed the existence of only some dependences. Therefore the presentation of full results is deliberately avoided in the research study, the study only focusing on the relationships identified as statistically significant.

\section{ACKNOWLEDGMENTS}

The research has been carried out as part of a research initiative financed by the Ministry of Science and Higher Education within the framework of the "Regional Initiative of Excellence" Programme for 2019-2022. Project no: 021/RID/2018/19. Total financing: PLN 11,897,131.40.

\section{REFERENCES}

Aczel, A. D., \& Sounderpandian, J. (2018). Statystyka w zarzadzaniu. Warszawa, PL: Wydawnictwo Naukowe PWN.

Al-Busaidi, K. A., \& Olfman, L. (2017). Knowledge-sharing through inter-organizational knowledge sharing systems. VINE Journal of Information and Knowledge Management Systems, 47(1), 110-126. doi/10.1108/VJIKMS-05-2016-0019

Arain, G. A., Bhatti, Z. A., Hameed, I., \& Fang, Y-H. (2019). Top-down knowledge hiding and innovative work behavior (IWB): a three-way moderated-mediation analysis of self-efficacy and local/foreign status. Journal of Knowledge Management, 24(2), 127-149. doi/10.1108/JKM-11-2018-0687

Aydogmus, C. (2019). Millennial knowledge workers. The roles of protean career attitudes and psychological empowerment on the relationship between emotional intelligence and subjective career success. Career Development International, 24(4), 297-314. doi/10.1108/CDI-06-2018-0165

Berardi, F. (2005). What does cognitariat mean? Work, desire and depression. Cultural Studies Review, 11(2), 57-63. doi/10.5130/csr.v11i2.3656

Bošković, A., \& Stojanović-Aleksić, V. (2018). Organic design as a factor of knowledge mangement in higher education. In V. Babić (Ed.). Contemporary Issues in Economics, Business and Management - EBM 2018 (pp. 59-67). Kragujevac, RS: Faculty of Economics University of Kragujevac.

Butler, C. (2016). Being appropriately professional: The interaction between professionalism, ICT and knowledge transfer. New Technology, Work and Employment, 31(2), 132145. doi/10.1111/ntwe.12064

Cillo, V., Garcia-Perez, A., Del Giudice, M., \& Vicentini, F. (2019). Blue-collar workers, career success and innovation in manufacturing. Career Development International, 24(6), 529-544. doi/10.1108/CDI-11-2018-0276 
Cotsomitis, J. A., (2018). Is the learning economy a viable concept for understanding the modern economy? International Journal of Social Economics, 45(3), 492-507. doi:10.1108/IJSE-01-2017-0025

Dabić, M., Lažnjak, J., Smallbone, D., \& Švarc, J. (2019). Intellectual capital, organisational climate, innovation culture, and SME performance: Evidence from Croatia. Journal of Small Business and Enterprise Development, 26(4), 522-544. doi/10.1108/JSBED-04-2018-0117.

Drucker, P. (1999). Knowledge-worker productivity: The biggest challenge. California Management Review, 41(2), 7994. doi/10.2307/41165987

Erickson, I., Jarrahi, M. H., Thomson, L., \& Sawyer, S. (2014). More than nomads: Mobility, knowledge work, and infrastructure. Retrieved March 30, 2020, from http://www. jarrahi.com/publications/EGOS_Erickson_Subtheme52.pdf

Gaižauskiene, L., \& Tunčikiene, Ž. (2016). The concept and role of knowledge worker and workplace fit in learning organisation. International Journal of Learning and Change, 8(3/4), 245-260. doi/10.3846/cibmee.2019.057

Heo, M., Toomey, N., \& Song, J. S. (2019). Self-evaluation of knowledge sharing through lens of social comparison theory. VINE Journal of Information and Knowledge Management Systems, 50(2), 291-304. doi/ 10.1108/VJIKMS-04-2019-0056

Holste, J. S., \& Fields, D. (2010). Trust and tacit knowledge sharing and use. Journal of Knowledge Management, 14(1), 128-140. doi/10.1108/13673271011015615

Horribe, F. (1999). Managing Knowledge Workers: New Skills and Attitudes to Unlock the Intellectual Capital in your Organization. Toronto, CA: John Wileys and Sons.

Imafidon, T. C. (2009). Managing the knowledge worker in a knowledge economy: Present problems and future prospects in African organizations. Ife PsychologIA, 17(2), 19-39. doi/10.4314/ifep.v17i2.45301

Jabagi, N., Croteau, A-M., Audebrand, L. K., \& Marsan, J. (2019). Gig-workers' motivation: Thinking beyond carrots and sticks. Journal of Managerial Psychology, 34(4), 192-213. doi/10.1108/JMP-06-2018-0255

Jayasingam, S., Govindasamy, M., \& Singh, S. K. G. (2016). Instilling affective commitment: insights on what makes knowledge workers want to stay. Management Research Review, 39(2), 266-288.
Kmiotek, K., \& Kopertyńska, M. W. (2018). Oczekiwania w zakresie motywowania pracowników wiedzy sektora IT w aktualnych uwarunkowaniach rynku pracy. Prace Naukowe Uniwersytetu Ekonomicznego we Wroctawiu, 511, 103-113. doi/10.15611/pn.2018.511.09

Kucharska, W., \& Erickson, G. S. (2019). The influence of ITcompetency dimensions on job satisfaction, knowledge sharing and performance across industries. VINE Journal of Information and Knowledge Management Systems, 50(3), 387407. doi/10.1108/vjikms-06-2019-0098

Lee, S. H. A., \& Lim, T-M. (2015). A study on the perception of POKM as the organizational knowledge sharing enabler. VINE Journal of Information and Knowledge Management Systems, 45(2), 292-331. doi/10.1108/VINE-09-2013-0052

Mahmoud, A. B., Fuxman, L., Mohr, I., Reisel, W. D., \& Grigoriou, N. (2020). We aren't your reincarnation! Workplace motivation across $\mathrm{X}, \mathrm{Y}$ and $\mathrm{Z}$ generations. International Journal of Manpower, 42(1), 193-209. doi/10.1108/ IJM-09-2019-0448

Mikuła, B. (2017). Koncepcja zarządzania wiedzą. In A. Krakowiak-Bal, P. Łukasik, B. Mikuła, A. Pietruszka-Ortyl \& U. Ziemiańczyk (Eds.). Zarzadzanie wiedza w rozwoju obszarów wiejskich (pp. 33-63). Warszawa, PL: Wydawnictwo C. H. Beck.

Olsen, K. M. (2016). The power of workers. Knowledge work and the power balance in Scandinavian countries. Employee Relations, 38(3), 390-405. doi.org/10.1108/ER-10-2014-0121

Pietersen, Ch. (2017). Organizational culture: A foundational perspective. African Journal of Economics and Management Studies, 8(3), 262-273. doi/10.1108/AJEMS-06-2016-0085

Pietruszka-Ortyl, A. (2020). Kooperacja w perspektywie zasobów niematerialnych organizacji. Warszawa, PL: Wydawnictwo C. H. Beck.

Rampersad, H. K. (2003) Total Performance Scorecard Reinventing Management to Achieve Performance with Integrity. Oxford, UK: Butterworth-Heinemann.

Razzaq, S., Shujahat, M., Hussain, S., Nawaz, F., Wang, M., Ali, M., \& Tehssen, S. (2019). Knowledge management, organizational commitment and knowledge-worker performance. The neglected role of knowledge management in the public sector. Business Process Management Journal, 25(5), 923-947. doi/10.1108/BPMJ-03-2018-0079 
Savović, S. (2017). Organizational culture differences and post-acquisition performance. The mediating role of employee attitudes. Leadership and Organization Development Journal, 38(5), 719-741. doi:10.1108/LODJ-02-2016-0043

Schein, E. (1985). Organizational Culture and Leadership. San Francisco, CA: Jossey-Bass.

Scott, P.B. (2005). Knowledge workers: social, task and semantic network analysis. Corporate Communications: International Journal, 10(3), 257-277. doi:10.1108/13563280510614519

Slijepčević, M., \& Kristić, J. (2019). Organizational culture and perceived effectiveness: A case study of an insurance company. Management: Journal of Sustainable Business and Management Solutions in Emerging Economies, 25(2), 29-40. doi/100.7595/management.fon.2019.0019

Stojanović-Aleksić, V., Erić Nielsen, J., \& Bošković, A. (2019). Organizational prerequisites for knowledge creation and sharing: Empirical evidence from Serbia. Journal of Knowledge Management, 23(8), 1543-1565. doi.org/10.22190/ FUEO1803189S

Sumbal, M. S., Tsui, E., Durst, S., Shujahat, M., \& Ali, S. M. (2020). A framework to retain the knowledge of departing knowledge workers in the manufacturing industry. VINE Journal of Information and Knowledge Management Systems, 50(4), 631-661. doi/10.1108/VJIKMS-06-2019-0086

Sun, Y., Wang, T., \& Gu, X. (2019). A sustainable development perspective on cooperative culture, knowledge flow, and innovation network governance performance. Sustainability, 11(21), 1-17. doi.org/10.3390/su11216126
Sveiby, K. (1997). The New Organizational Wealth. San Francisco, CA: Berret-Koehler.

Tammelin, M., Koivunen, T., \& Saari, T. (2017). Female knowledge workers and the illusion of working-time autonomy. International Journal of Sociology and Social Policy, 37(9/10), 591-604. doi:10.1108/IJSSP-08-2016-0100

Trequattrini, R., Massaro, M., Lardo, A., \& Cuozzo, B. (2019). Knowledge transfer and managers turnover: Impact on team performance. Business Process Management, 25(1), 6983. doi/10.1108/BPMJ-06-2017-0169

Tsai, S-P. (2018). Innovative behaviour of knowledge workers and social exchange attributes of financial incentive: Implications for knowledge management. Journal of Knowledge Management, 22(8), 1712-1735. doi/10.1108/JKM07-2017-0293

Wood, S. (2013). Generation Z as consumers: Trends and innovation. Retrieved October 5, 2019, from https:/iei.ncsu. edu/wp-content/uploads/2013/01/GenZConsumers.pdf

Zhang, Z. (2018). Organizational culture and knowledge sharing: Design of incentives and business processes. Business Process Management, 24(2), 384-399. doi/10.1108/ BPMJ-08-2015-0119

\author{
Received on $4^{\text {th }}$ February 2021, \\ after revision, \\ accepted for publication on $12^{\text {th }}$ July 2021 \\ Published online on $2^{\text {nd }}$ August 2021
}

Anna Pietruszka-Ortyl is an assistant professor at the College of Management and Quality Sciences of the Cracow University of Economics, Republic of Poland, where she obtained her Ph.D. degree in the management scientific field. The key areas of her scientific research are intangible resources management, organizational behavior, knowledge workers and management paradigms. 


\title{
KULTURA SARADNJE MEĐU RADNICIMA ZNANJA: STUDIJA IT SEKTORA U POLJSKOJ
}

\author{
Anna Pietruszka-Ortyl \\ Cracow University of Economics, College of Management and Quality Sciences, Department of \\ Organizational Behavior, Poland
}

Radnici znanja su osobe koje čine jezgro moderne organizacije. Njihov položaj u preduzeću je jedinstven, što usložnjava proces izgradnje sistema podsticaja i formalnog uticaja menadžera na njihove aktivnosti. Sa statusom „izuzetno pametnih”, oni usvajaju stavove koji ograničavaju protok znanja, ili ga čak i namerno skrivaju. Pružanje podrške organizacionoj kulturi je od presudnog značaja za motivaciju radnika znanja, koji bi svojim znanjem trebalo da daju doprinos unutar same organizacije. Glavni cilj ovog istraživanja je da se identifikuju sklonosti radnika znanja kada je u pitanju organizaciona kultura. U radu se dosledno ukazuje na pravce razvoja organizacione kulture IT kompanija u Poljskoj, a u skladu sa stavovima stručnjaka čiji je cilj podsticanje njihovog uključivanja u sprovođenje konkretnih podprocesa difuzije znanja. Rad se zasniva na empirijskom istraživanju sprovedenom 2020, na uzorku od 105 radnika znanja zaposlenih u IT sektoru u Poljskoj.

Ključne reči: organizaciona kultura, radnik znanja, difuzija znanja, saradnja, IT sektor

JEL Classification: D23, D64, D83, D91 